DOI: $10.46340 /$ eppd.2020.7.4.14

Dmytro Osypov

ORCID ID: https://orcid.org/0000-0002-7132-5991

Dnipropetrovsk Regional Institute for Public Administration of the National

Academy for Public Administration under the President of Ukraine

\title{
PHENOMENOLOGY OF PROFESSIONAL INTERESTS IN PROFESSIONAL DEVELOPMENT OF PUBLIC OFFICERS
}

In the article, in the context of professional formation and development of public officers, their professional interests are comprehensively studied. These interests are considered as an acmeological condition and a subjective factor, a determinant of personal professionalism and professional activity. To form professional interests, the spheres of interaction between the potentials of a public official's personality and the professional environment of public service (public authority) are defined. In this regard, the motivational, self-actualizing, identification, developing, group-building and team-building orientations of the professional interests of this professional group are specified. Based on the acmeological approach, the author identifies the general directions of the formation and evaluation of professional interests in public officials. From the position of acmeology, the place of professional interests is determined among the criteria and indicators of personality professionalism.

Keywords: public service, professional interests, professional orientation, motivation, professionalism, acmeology.

Introduction. Interests, their phenomenological characteristics are a separate area of personality research. Modern scientific research on the study of professional interests lacks a comprehensive approach and consistency, which further determines the relevance of this article. Professional interest is one of the types of general interest, it is formed in a variety of interests and inclinations, expresses a positive attitude of the person to the profession. Interest is directed to a specific profession, it indicates the direction and potential of the orientation of the individual, the need to master the profession, the desire to self-actualize in it. The study of the interests of personnel is very relevant from the position of the formation of internal professional motivation of individual workers, groups, temporary and permanent teams included in the process of professional work. Professional development takes place in an environment where a certain balance of people with a variety of interests arises and is maintained in the team.

The purpose of the article is to develop the phenomenological characteristics and importance of professional interests, to determine the role of the professional interests of public officers in the process of their professional formation and development.

Basic part. Yu. V. Yarmak singles out national, socio-political, political, corporate, state, legislative and executive branches of government, bureaucracy, party interests, vital, human, personal, group, general, joint, majority interests, intellectual, diverse, and integrative ${ }^{1}$. Interests, in general, are important in determining the supporting concepts of the sciences of management, state administration, and public administration. The concept of "interests" is often used along with the concepts of "focus", "motives", "attitudes", "orientation", "inclinations", "tendency", "ideals", "values"2.

\footnotetext{
${ }^{1}$ Ярмак Ю.В. (2002). Профессионализм политической элиты:: теория и практика. Москва: Изд-во Московского гос. социального ун-та, 26, 35, 59, 60-62, 66, 87, 91, 98, 170.

2 Абдалина, Л.В. (2008). Психолого-акмеологическая модель развития профессионализма педагога: автореферат диссертации доктора психологических наук. Тамбов, 21; Выготский, Л.С. (2005). Проблема возрастной периодизации детского развития. Психология развития. Москва: ЧеРо; Кропотина, Н.М. (2014). Формирование профессиональных компетенций как основа профессиональной самореализации человека в XXI веке. Сочиально-профессиональная мобильность в ХХІ веке: сборник материалов и докладов международной конференции. Екатеринбург: Изд-во Рос. гос. проф.-пед. ун-та, 246-247; Шпекторенко I. (2016). Підходи до професійної мобільності державного службовця в сучасних концепціях професіоналізації. Державне управління та місиеве самоврядування: збірник наукових пращь ДРІДУ, 3 (30). Дніпро: ДРІДУ НАДУ, $126-133$.
} 
The professional activities of a public officer are formed and developed, first of all, in the social environment. The mentioned conclusions of E. Erickson for the professional public service environment mean the following:

(1) The development of the personality of a public officer is determined by his willingness to show a steady interest in the professional environment, which can change, learn about it and interact with it.

(2) The public officer profession, in principle, seeks such an arrangement when it meets the indicated readiness, encourages this continuous chain of potentials (employee and environment) to interact, trying to ensure and stimulate the proper speed and sequence of their disclosure. This is the "support of the professional community of public officers". The professional environment of the public service should help the employee realize his interests and abilities, develop a leadership and leadership style, a scenario of professional development, contribute to the implementation of the natural state of human potential: its feasibility ${ }^{1}$, when a person is considered as an active subject of his life, subjectivity itself is the highest level of personality development.

Conclusions by E. Erickson ${ }^{2}$, it is quite possible to design for a professional public service environment in which the personality of a public officer is directly formed and developed, where he is formed as a competent employee, and later as a professional.

In one of his works, L.S. Vyhotskyi noted the dependence of success on a decrease in interest in classes and a general decrease in working capacity ${ }^{3}$. S. V. Bondarenko defined professional interest as "a positive attitude of the person to the profession", it is one of the types of general interest, its specificity lies in the fact that it is aimed at a particular profession, and the general interest is on the subject or phenomenon of reality ${ }^{4}$. An outstanding researcher in the theory of professional self-determination and professional development, E.F. Zeer, while studying the aspect of the psychological characteristics of the interaction between the individual and the profession, especially highlighted the situation with a variety of interests and inclinations. Gradually, interests became a separate area of personality research. This is the quality necessary for the profession that interests the individual. The concept of "interests" is often used by E.F. Zeer along with the concepts of "tendency," "motives," "attitudes," and "orientations." On the whole, the interests in the personality structure are related by E.F. Zeer to the component of a professional orientation like motives (intentions, interests, inclinations, ideals) ${ }^{5}$.

A motive is a peculiar reaction of people to interests, and therefore to conscious needs ${ }^{6}$. From this point of view, public officers need a policy of personnel selection, placement, and professional training (professional development), where only interested and capable, competent people hold managerial and nonmanagerial positions. Professional interest as one of the motives, as a key link in the motivational sphere, as a need to master a profession, a desire to fulfil oneself in it is considered by V. Soldatenko ${ }^{7}$. E.A. Klimov points to the dependence of the dynamics of working capacity, fatigue, conditions of labour over-saturation, sadness, labour return from the interest in work, in particular. Interests, from his perspective, underlie the processes that determine the effectiveness of group and team-building ${ }^{8}$. Interests determine the formation of various types of personnel motivation, not excluding professional.

Modern theoretical studies of interests indicate that the personal and professional aspects of the development of the personality of a public officer are determined by his professional competence, capacity for work, professional self-determination, professional orientation, willingness to show a steady interest in the dynamic professional environment of public service, in its knowledge and interaction with it. The connection of professional interests with the formation of other qualities of the staff confirms their direct connection with the process of professional formation and professional activity.

\footnotetext{
${ }^{1}$ Абульханова-Славская, К.А. (1990). Стратегия жизни. Москва: Мысль, 21.

2 Эриксон, Э. (2005). Эпигенетическая карта. Психология развития. Москва: ЧеРо, 59.

${ }^{3}$ Выготский, Л.С. (2005). Проблема возрастной периодизации детского развития. Психология развития. Москва: ЧеРо, 18.

${ }^{4}$ Бондаренко, С.В. (2011). Розвиток проблеми формування професійного інтересу у психолого-педагогічній науці. Педагогіка та психологія, 40 (1), 135-139. <http://nbuv.gov.ua/UJRN/znpkhnpu_ped_2011_40(1)_24>.

5 Зеер, Э.Ф. (2003). Психология профессий: учебное пособие. Москва: Академ. Проект; Екатеринбург: Деловая книга.

${ }^{6}$ Колот, А.М. (2002). Мотивація персоналу: підручник. Київ: КНЕУ.

${ }^{7}$ Солдатенко, В.М. (2016). Формування професійного інтересу в студентів технічних ВНЗ.

$<$ https:/www.kpi.kharkov.ua/archive/Наукова_періодика/elits/2012/30/Формування\%20професійного\%20інтерес у\%20в\%20студентів\%20технічних\%20ВНЗ.p.pf>.

${ }^{8}$ Климов, Е.А. (1997). Основы психологии: учебник для вузов. Москва: Культура и спорт, ЮНИТИ.
} 
Interests are a key link in the internal psycho-emotional, need-motivational, value-motivational spheres of a person; professional interests are related to professional intentions, professional expectations, professional fitness, professional satisfaction ${ }^{1}$, determine the value orientation of a person, affect the formation of various types of the internal motivation of personnel (not excluding professional), as well as the employee's reaction to external motivation, which is important in the processes of group and team-building in public authorities. Interests are associated with a system of personal values, or "types of competency" (initiative, leadership, direct interest in the mechanisms of the organization and society as a whole ${ }^{2}$.

So, interests occupy an important place both in the formation of internal professional motivation of staff and in the sense of the degree of formation of the leader, employee, employee, in the activity aspects that express the maturity of professional competence, professional activity, its "professionalism of activity" (according to the classification of levels of professionalism, provided by A.A. Derkach and other representatives of acmeological science).

In his book, J. Raven calls the qualities of a modern employee, reflecting the formation of various aspects of social and professional interests ${ }^{3}$. Ye.Ye. Vakhromov, exploring the self-actualization of a specialist, defines the concept of "competence in professional activity" including through the ability to combine his personal interests with the interests of the group and subordinate his interests to achieving common success. Interests, including professional ones, determine the content, nature and tendency of selfactualization ${ }^{4}$."A man acts actively then," continues Ye.A. Klimov, when he wants and can, in other words, when his motives (interests, needs, emotional relationships, beliefs, nonpareil (ideals) are mobilized and at least the initial methods and techniques of memory actions are formed"5.

You can notice the essential similarity, and therefore the relationship of needs, motives and interests. If a person's needs are a feeling of lack of something, then interests are conscious needs, a source of activity, an objective need to perform certain functions to satisfy needs. Motives are the conscious causes of activity, the person's motivation for something. Motives appear almost simultaneously with the emergence of needs and interests, passing certain stages similar to the stages of forming interests.

A motive is a peculiar reaction of people to interests, and therefore to conscious needs. Interests must be understood along with the inclinations, inclinations of a person. Together, they largely determine the professional orientation of a person, his intrinsic motivation, the orientation of this motivation, the content, nature and orientation of self-actualization. In turn, from our position, for the staff of public authorities, these qualities in all their diversity can only form the basis of professional consulting and evaluation, since a wide range of goals and objectives of public authorities require the formation of a larger set of professional competencies and professionally important qualities.

Professional interests are one of the acmeological conditions and factors of professionalism of public officers. Acmeological conditions are significant circumstances that determine the achievement of high professionalism of the individual and activity. Acmeological factors (factors) are the main reasons that have the nature of driving forces, the main determinants of professionalism ${ }^{6}$. In acmeological science, three types of these factors are differentiated as follows: objective, related to the real system of professional activity (sometimes manifested as criteria related to external assignment, that is, norms); subjective measures of the success of professional activities associated with individual prerequisites: motives, orientation, interests, competence, skilfulness, etc. (the degree of their manifestation is subjective reasons that contribute to the growth of professionalism); objective-subjective, associated with the organization of the professional environment, the professionalism of managers, and quality management ${ }^{7}$. Acmeological factors reflect individual manifestations in activities and professional development. The most important general

\footnotetext{
${ }^{1}$ Шпекторенко, I. (2016). Підходи до професійної мобільності державного службовця в сучасних концепціях професіоналізації. Державне управління та місиеве самоврядування, 3 (30). Дніпро: ДРІДУ НАДУ, $126-133$.

${ }^{2}$ Равен, Дж. (2002). Компетентность в современном обществе: выявление, развитие и реализация. Москва: Когито Центр.

${ }^{3}$ Равен, Дж. (2002). Компетентность в современном обществе: выявление, развитие и реализация. Москва: Когито Центр.

${ }^{4}$ Вахромов, Е.Е. Самоактуализация специилиста, менеджера в профессиональной деятельности: проблемы и возможности. $<$ http://hpsy.ru/public/x1509.htm>.

${ }^{5}$ Климов, Е.А. (1997). Основы психологии: учебник для вузов. Москва: Культура и спорт, ЮНИТИ.

6 Зазыкин, В.Г. Акмеографический подход в акмеологических исследованиях. Акмеология: методология, методы и технологии. <http://akmeolog.narod.ru/kus.html\#9>.

${ }^{7}$ Деркач, А.А. (общ. ред.) (2005). Акмеологический словарь. Москва: Изд-во РАГС.
} 
acmeological factors (or acmeological invariants of professionalism: the main qualities and skills of a professional, providing high performance and stability of activity, regardless of its content and specificity), as studies have shown, are special skills, stress resistance, developed psychomotor skills, high level of attention, high level of motivation, need for achievements, high personal and professional standards, desire for self-realization; social responsibility, value orientations, serving the state interests, dedication; high levels of professional perception, thinking and anticipation; the prestige of professional excellence; and the prestige of professionalism, as well as everything subjective, which contributes to the growth of professionalism ${ }^{1,2,3}$.

In the process of professionalization, we emphasize that the harmonious combination of objective and subjective factors is relevant, which must be taken into account in the process of formation and assessment of the professional interests of public officers. V.A. Tolochek points out the importance of such qualities in the formation of professionalism: trainability, conscious intelligence, creativity, creative abilities; psychological and managerial competence; complex psychological education: the style of professional activity, the style of leadership ${ }^{4}$.

According to acmeology, professional interests should include a specialist's acmeogram, consisting of six substructures. Interests are included in substructure 2: individuality, which interacts with substructures: abilities, orientation, characterological features and moral qualities; professional characteristics; and acmeological invariant of professionalism ${ }^{5}$. We note that the specialist's interests (social (general)) or professional can be attributed not only to the substructure of the individual but also to the substructure of the orientation of the individual. Although, from a different perspective, professional interests influence the formation of all substructures defined in the specialist's acmeogram. Secondly, the content of the acmeogram is presented in such a way that it does not completely correlate with the criteria of professionalism defined by the acmeologists themselves.

An important criterion for the formation of professional interests is professional identification. Identity is an important condition for effective professional activity, the expression of a subjective attitude to one's professional affiliation ${ }^{6}$. E.A. Klimov, whose research laid the foundation of the scientific works of acmeologists proper, interests were the basis of the processes that determine the effectiveness of group and team building. Acmeologists consider the team (from Latin "collectifious": collective) as a kind of small social group, its special quality, manifested in compatibility, harmony, cohesion, coherence of social, group and personal goals, interests, values ${ }^{7}$, and as a subject of joint activity and relations developing between its individual participants, when a group goes through several stages of development in its development: creation, formation, and maturity.

At the maturity stage, an acme of a group is possible, the integral indicator of which is the transformation of a group into a community based on common interests, goals, and values ${ }^{8}$, and the characteristics of the collective as a subject are self-government, the commonality of intragroup goals, interests, values; transformation from the outside of the intended goals and objectives into significant ones for the team and each of its members; the ability and willingness of team members for cooperation, mutual assistance, interchangeability, a positive emotional attitude ${ }^{9}$, and many other personal and professional qualities, in the determination of which acmeologists, as we see, do not have a single position.

\footnotetext{
1 Деркач, А.А. (общ. ред.) (2004). Акмеология: учебник. Москва: Изд-во РАГС, 167.

2 Деркач, А.А., Маркова, А. К. (1999). Профессиограмма государственного служашего. Москва: РАГС.

3 Зазыкин, В.Г. Акмеографический подход в акмеологических исследованиях. Акмеология: методология, методы и технологии. <http://akmeolog.narod.ru/kus.html\#9>.

4 Толочек, В.А. «Акме», профессионализм и социальная адаптаџия человека: периодизаџия развития и типологии социальной активности человека. $<\mathrm{http}: / / \mathrm{kkme} 31$. narod.ru/25.html $>$.

5 Деркач, А.А. (общ. ред.) (2004). Акмеология: учебник. Москва: Изд-во РАГС, 69-70.

6 Липовська, Н.А., Маланчій, М.О. (2013). Професійна ідентичність державних службовців як наукова проблема. Аспекти публічного управління, 2(2), 58; Маланчій, М.О. (2016). Формування професійної ідентичності персоналу Державної прикордонної служби Украйни: автореферат дисертації кандидата державного управління. Дніпро; Орестова, В.Р. (2010). Акмеологическая концепция идентификации государственных служащих: автореферат диссертации доктора психологических наук. Москва.

${ }^{7}$ Абдалина, Л.В. (2008). Психолого-акмеологическая модель развития профессионализма педагога: автореферат диссертации доктора психологических наук. Тамбов; Деркач, А.А. (общ. ред.) (2005). Акмеологический словарь. Москва: Изд-во РАГС; Деркач, А.А. (общ. ред.) (2004). Акмеология: учебник. Москва: Изд-во РАГС. 8 Деркач, А.А. (общ. ред.) (2004). Акмеология: учебник. Москва: Изд-во РАГС, 176.

9 Деркач, А.А. (общ. ред.) (2005). Акмеологический словарь. Москва: Изд-во РАГС.
} 
Acmeology offers criteria and indicators of personality professionalism: achieving a high level of qualification, conscious change and development of oneself in the course of one's professional activity, making an individual creative contribution to one's profession; finding an individual destination in your profession, focus on high achievements, a harmonious combination of personal interests and the interests of society $^{1}$. From our point of view, the means of determining the criteria and indicators of personality professionalism are methods, techniques, techniques and technologies, methods for assessing the personality professionalism (or components, areas of professionalism), a set of qualities that make up this type of professionalism.

Conclusions. Thus, modern theoretical studies of interests allow us to conclude that public officers should base their professional interests on the interests of the state, the public sector of society, all segments of society, the interests of the citizen and the individual. The interest of the subjects and objects of the public administration process is an important condition for ensuring not only the management itself but also its anticipatory nature.

Professional interests are related to professional intentions, professional expectations, professional fitness, professional satisfaction, and focus on professional self-actualization. The profession of a public officer should, first of all, provide "support for the professional community of public officers", equip the public officer, meet the readiness and encourage the readiness of the employee for productive work, encourage the potential of the professional environment and the employee of the public authority to interact, strive to ensure and stimulate the proper speed and consistency of the disclosure of these potentials during the person's stay in the profession.

The personal and professional aspects of the development of the personality of a public officer are determined by his capacity for work, professional self-determination, professional orientation, willingness to show a steady interest in the dynamic professional environment of public service, in its knowledge and interaction with it, professional competence, and willingness to work in a group and team.

Interests as a whole occupy an important place in understanding the degree of formation of a leader, worker (clerk), employee, and, in particular, in activity aspects expressing the maturity of professional competence, professional activity, "professional activity", when professional competence itself is formed as the ability to combine one's interests with the interests of the group and subordinate your interests to achieving common success.

Interests are the basis for the processes that determine the effectiveness of group and team building.

Professional interests can be simultaneously considered as an acmeological condition and a subjective factor, a determinant of professionalism, which is a set of professionally important qualities reflect the essential characteristics of personal and professional development of a public officer as an acmeological phenomenon.

The directions of formation and evaluation of professional interests in public officers based on the acmeological approach are the direction of normative and legal impact on the public service, taking into account social norms, or socio-legislative regulation; the direction of formation of worldview and professional behaviour; and direction providing professional activity of public officers.

\section{References:}

1. Abdalina, L.V. (2008). Psihologo-akmeologicheskaya model razvitiya professionalizma pedagoga [Psychological and acmeological model for the development of teacher professionalism]: avtoref. dis. ... dokt. psihol. n. Tambovskiy gos. un-t im. G. R. Derzhavina. Tambov. [in Russian].

2. Abulhanova-Slavskaya, K.A. (1990). Strategiya zhizni [Life strategy]. Moscow: Myisl. [in Russian].

3. Derkach, A.A. (2005). Akmeologicheskiy slovar (2-e izd.) [Acmeological dictionary]. Moscow: Izd-vo RAGS. [in Russian].

4. Derkach, A.A. (2004). Akmeologiya: uchebnik [Acmeology: a textbook]. Moscow: Izd-vo RAGS. [in Russian].

5. Bondarenko, S.V. (2011). Rozvytok problemy formuvannia profesiinoho interesu u psykholoho-pedahohichnii nautsi [Development of the problem of formation of professional interest in psychological and pedagogical science]. Pedahohika ta psykholohiia, no. 40 (1), 135-139.<http://nbuv.gov.ua/UJRN/znpkhnpu_ped_2011_40(1)_24>. [in Ukrainian].

6. Vahromov, E.E. Samoaktualizatsiya spetsialista, menedzhera v professionalnoy deyatelnosti: problemyi $i$ vozmozhnosti [Self-actualization of a specialist, manager in a professional activity: problems and opportunities]. $<$ http://hpsy.ru/public/x1509.htm>. [in Russian].

7. Vyigotskiy, L.S. (2005). Problema vozrastnoy periodizatsii detskogo razvitiya [The problem of age periodization of child development]. Psihologiya razvitiya. Moscow: CheRo. [in Russian].

1 Деркач, А.А. (общ. ред.) (2005). Акмеологический словарь. Москва: Изд-во РАГС. 
8. Derkach, A.A., Markova, A.K. (1999). Professiogramma gosudarstvennogo sluzhaschego [Public servant professiogram]. Moscow: RAGS. [in Russian].

9. Zazyikin, V. G. Akmeograficheskiy podhod v akmeologicheskih issledovaniyah. Akmeologiya: metodologiya, metodyi i tehnologii [Acmeographic approach in acmeological research]. $<$ http://akmeolog.narod.ru/kus.html\#9>. [in Russian].

10. Zeer, E.F. (2-e izd.). (2003). Psihologiya professiy: uchebnoe posobie [Occupational Psychology: Study Guide]. Moscow: Akadem. Proekt; Ekaterinburg: Delovaya kniga. [in Russian].

11. Klimov, E.A. (1997). Osnovyi psihologii: uchebnik dlya vuzov [Basics of Psychology: a textbook for universities]. Moscow: Kultura i sport, YuNITI. [in Russian].

12. Kolot, A.M. (2002). Motyvatsiia personalu: pidruchnyk [Staff motivation: a textbook]. Kyiv: KNEU. [in Ukrainian].

13. Kropotina, N.M. (2014). Formirovanie professionalnyih kompetentsiy kak osnova professionalnoy samorealizatsii cheloveka $\mathrm{V}$ XXI veke [The formation of professional competencies as the basis of professional human selfrealization in the XXI century]. Sotsialno-professionalnaya mobilnost v XXI veke. Ekaterinburg: Izd-vo Ros. gos. prof.-ped. un-ta, 246-247. [in Russian].

14. Lypovska, N.A., Malanchii, M.O. (2013). Profesiina identychnist derzhavnykh sluzhbovtsiv yak naukova problema [Professional identity of civil servants as a scientific problem]. Aspekty publichnoho upravlinnia, no. 2(2), 55-61. [in Ukrainian].

15. Malanchii, M.O. (2016). Formuvannia profesiinoi identychnosti personalu Derzhavnoi prykordonnoi sluzhby Ukrainy [Formation of professional identity of the staff of the State Border Guard Service of Ukraine]. Dnipro. [in Ukrainian].

16. Orestova, V.R. (2010). Akmeologicheskaya kontseptsiya identifikatsii gosudarstvennyih sluzhaschih [Acmeological concept for the identification of public servants]. Moscow. [in Russian].

17. Raven, Dzh. (2002). Kompetentnost v sovremennom obschestve: vyiyavlenie, razvitie i realizatsiya [Competence in modern society: identification, development and implementation]. Moscow: Kogito Tsentr. [in Russian].

18. Soldatenko, V.M. Formuvannia profesiinoho interesu v studentiv tekhnichnykh VNZ [Formation of professional interest in students of technical universities]. <https:/www.kpi.kharkov.ua/archive/Наукова_періодика/elits/ 2012/30/Формування\%20професійного\%20інтересу\%20в\%20студентів\%20технічних\%20BН3.pdf >. [in Ukrainian].

19. Tolochek, V.A. «Akme», professionalizm i sotsialnaya adaptatsiya cheloveka: periodizatsiya razvitiya i tipologii sotsialnoy aktivnosti cheloveka [«Acme», professionalism and social adaptation of a person: periodization of development and typology of human social activity]. <http://akme31.narod.ru/25.html $>$. [in Russian].

20. Shpektorenko, I. (2016). Pidkhody do profesiinoi mobilnosti derzhavnoho sluzhbovtsia v suchasnykh kontseptsiiakh profesionalizatsii [Approaches to professional mobility of civil servants in modern concepts of professionalization]. Derzhavne upravlinnia ta mistseve samovriaduvannia, no. 3 (30). Dnipro: DRIDU NADU, 126-133. [in Ukrainian].

21. Erikson, E. (2005). Epigeneticheskaya karta. Psihologiya razvitiya [Epigenetic map. Developmental psychology]. Moscow: CheRo. [in Russian].

22. Yarmak, Yu.V. (2002). Professionalizm politicheskoy elityi: teoriya i praktika [Professionalism of the political elite: theory and practice]. Moscow: Izd-vo Moskovskogo gos. sotsialnogo un-ta. [in Russian]. 